\title{
EFFECT OF LARGE DOSES OF ZING BACITRACIN ON VOLUNTARY INTAKE, MASTICATION AND DIGESTIBILITY OF HAY IN ADULT RUMINANTS
}

\author{
LiISA SyrJäLÄ \\ University of Helsinki, Department of Animal Husbandry
}

Received July 15, 1970

\begin{abstract}
Two cows were used in the trials. They received timothy hay as their only feed. As the antibiotic doses were increased during the experiment, the cows' hay consumption decreased. The maximum zinc bacitracin doses were $80-100 \mathrm{mg}$ per $\mathrm{kg}$ live weight.

Sieve fractionations of the faeces were made to investigate the efficiency of the mastication of the feed. The crude faeces fractions increased with increases in the zinc bacitracin doses, indicating that the mastication of the food was depressed.

Lignin was used as an indicator when investigating the digestibility of the food. The results show that zinc bacitracin depressed the digestibility of the plant cell wall substances. There was also a decrease in the digestibility of the other constituents of the hay.
\end{abstract}

It has been known for about twenty years by now that antibiotics, in very small doses, improve the utilization of food and increase growth in chichkens and pigs. Antibiotics have also been shown to have a favourable effect on the growth of calves (CunHA 1955). The case of ruminants is in a class by itself as regards antibiotics given as a feed supplement. The digestion of ruminants depends to a great degree on the activity of the rumen microbes and antibiotics may cause changes in the composition of this microflora and -fauna (Munch-Petersen and Armstrong 1968, Purser et al. 1965). Many in vitro trials (Hungate 1966, Fulgham et al. 1968, Prins 1969) have shown that antibiotics are injurious to the protozoa and cellulose digesting bacteria and so indirectly decrease the digestibility of roughage. Feeding trials with adult ruminants have given conflicting results (Rusoff et al. 1952, Chance $t$ al. 1963, Jukes 1955, Kloppenstein $e t$ al. 1969, Mrtchell et al. 1969). In general, the addition of antibiotics to feeds for adult ruminants is not recommended (McDonald et al. 1966).

The purpose of this study is to study the effect of large oral antibiotic doses on the voluntary intake, mastication and digestibility of hay in adult cows. The word mastication means in this work the mincing of the feed in the whole alimentary tract. Zinc bacitracin was chosen because it is not absorbable from the alimentary tract (A-L., Zinc Bacitracin 1962). 


\section{Experimental procedure}

Two dry Ayrshire cows were used in this experiment. The cows, Ilmu and Nopea, were of different ages and sizes. Ilmu was 7 years old and weighed $674 \mathrm{~kg}$ at the beginning of the experiment, while Nopea was 3 years and weighed $417 \mathrm{~kg}$.

The cows were fed solely on chopped timothy hay. It was given ad libitum, but the amount consumed at each feeding time was noted. The animals were fed twice a day. They had free access to water.

The preparation used in this experiment was Norwegian A-L Zinc Bacitracin containing $54 \%$ zinc bacitracin. The amounts given here represent pure Zn-bacitracin. Bacitracin powder in a capsule was pushed directly down the throat of the cow. It was found more practical to give the antibiotic in this way than to mix it with water and give it from a bottle, as had been done in the preliminary trials.

The preliminary trials indicated that $20 \mathrm{~g}$ /day of zinc bacitracin would be suitable for the first experimental period of the cow Nopea. The antibiotic ration of the cow Ilmu in the corresponding period was $25 \mathrm{~g} / \mathrm{day}$. So the relation of zinc bacitracin to the amount of hay consumed in Period 0 (only hay given) was about the same for both cows, and averaged $2.5 \mathrm{~g}$ of zinc bacitracin per $\mathrm{kg}$ hay.

The amounts of pure zinc bacitracin ( $\mathrm{g} /$ day) given in the different experimental periods were as follows:

$\begin{array}{ccc}\text { period } & \text { cow Nopea } & \text { cow Ilmu } \\ 1 & 20 & 25 \\ 2 & 28 & 35 \\ 3 & 40 & 50\end{array}$

\section{Results and discussion}

Vol u n t a r y in ta ke. Tables 1 and 2 show that zinc bacitracin has an individual effect on the consumption of hay. As from Period 0 (no Zn-bacitracin) to Period 1 (smallest amounts of $\mathrm{Zn}$-bacitracin), the average daily hay consumption by the cow Nopea diminished $2.7 \mathrm{~kg}$ whereas by cow Ilmu it diminished only $0.5 \mathrm{~kg}$. Table 1 shows that the average daily hay consumption of the cow Nopea was about the same in Periods 1 and 2, but that the consumption dropped sharply when the antibiotic dose was increased to $40 \mathrm{~g} /$ day (Period 3 ). Table 2 shows that the daily hay consumption of the cow Ilmu diminished later in Period 3. This cow tolerated $50 \mathrm{~g}$ of antibiotic for 8 days and was then taken ill with diarrhoea. The return of appetite in the cows was investigated by giving them only hay ad libitum after the antibiotic treatment. This test was made after Period 3. It took one week before Ilmu's hay consumption was back to normal, while Nopea's recovered within $2-3$ days.

Efficiency of mastication. The efficiency of the mastication of the hay with different doses of zinc bacitracin was studied by taking sieve analyses of the faeces (Palohermo, Syrjälä and Vainio 1968). The results are shown in Table 3.

The fractions remaining on the sieves consist of the exogenous part of the faeces (PALOhermo 1962, PALOHEIMo 1966), and contain mainly plant cell wall substances derived from the food. The fraction passing through all the sieves consists to a great degree of 
Table 1. Daily hay consumption (kg) of the cow Nopea in different experimental periods.

\begin{tabular}{|c|c|c|c|c|}
\hline $\begin{array}{l}\text { Experi- } \\
\text { mental } \\
\text { day }\end{array}$ & $\begin{array}{c}\text { Period } 0 \\
\text { (no Zn- } \\
\text { bacitracin) }\end{array}$ & $\begin{array}{c}\text { Period } 1 \\
(20 \mathrm{~g} / \text { day } \mathrm{Zn}- \\
\text { bacitracin })\end{array}$ & $\begin{array}{c}\text { Period } 2 \\
(28 \mathrm{~g} / \text { day } \mathrm{Zn}- \\
\text { bacitracin })\end{array}$ & $\begin{array}{c}\text { Period } 3 \\
(40 \mathrm{~g} / \text { day } \mathrm{Zn}- \\
\text { bacitracin })\end{array}$ \\
\hline 1 & 7.7 & 5.2 & 5.4 & 6.2 \\
\hline 2 & 7.4 & 3.0 & 7.4 & 0.4 \\
\hline 3 & 7.5 & 3.3 & 6.0 & \\
\hline 4 & 8.1 & 4.6 & 5.8 & \\
\hline 5 & 9.4 & 7.1 & 5.8 & \\
\hline 6 & 9.7 & 5.2 & 6.3 & \\
\hline 7 & 7.1 & 6.6 & & \\
\hline 8 & 7.6 & 7.1 & * & \\
\hline 9 & 7.6 & 6.6 & & \\
\hline 10 & 9.0 & 5.8 & & \\
\hline 11 & 9.1 & & & \\
\hline 12 & 8.7 & & & \\
\hline 13 & 8.0 & & & \\
\hline Average & 8.2 & 5.5 & 6.1 & \\
\hline
\end{tabular}

Table 2. Daily hay consumption (kg) of the cow Ilmu in different experimental periods.

\begin{tabular}{|c|c|c|c|c|}
\hline $\begin{array}{l}\text { Experi- } \\
\text { mental } \\
\text { day }\end{array}$ & $\begin{array}{c}\text { Period 0 } \\
\text { (no Zn- } \\
\text { bacitracin) }\end{array}$ & $\begin{array}{c}\text { Period } 1 \\
(25 \mathrm{~g} / \text { day } \mathrm{Zn}- \\
\text { bacitracin })\end{array}$ & $\begin{array}{c}\text { Period } 2 \\
(35 \mathrm{~g} / \text { day } \mathrm{Zn}- \\
\text { bacitracin })\end{array}$ & $\begin{array}{c}\text { Period } 3 \\
(50 \mathrm{~g} / \text { day } \mathrm{Zn}- \\
\text { bacitracin })\end{array}$ \\
\hline 1 & 9.6 & 11.0 & 9.2 & 7.5 \\
\hline 2 & 5.8 & 8.3 & 7.7 & 6.8 \\
\hline 3 & 8.9 & 8.6 & 7.7 & 4.8 \\
\hline 4 & 10.3 & 8.5 & 8.5 & 4.7 \\
\hline 5 & 10.2 & 6.1 & 9.6 & 6.5 \\
\hline 6 & 10.5 & 8.0 & 7.8 & 3.7 \\
\hline 7 & 9.1 & 9.4 & 6.0 & 3.2 \\
\hline 8 & 9.3 & 9.8 & & 1.0 \\
\hline 9 & 8.5 & 10.3 & & \\
\hline 10 & 9.6 & 8.7 & & \\
\hline 11 & 9.0 & 7.1 & & \\
\hline 12 & 9.4 & & & \\
\hline 13 & 9.5 & & & \\
\hline 14 & 8.4 & & & \\
\hline Average & 9.2 & 8.7 & 8.1 & 4.8 \\
\hline
\end{tabular}

endogenous and bacterial material and probably of cell wall particles small enough to pass through the $0.1 \mathrm{~mm}$ sieve. Table 3 indicates that $\mathrm{Zn}$-bacitracin tended to depress slightly the mincing of the hay. 
Table 3. Percentages of dry matter of faeces remaining on different sieves.

\begin{tabular}{|c|c|c|c|c|c|c|c|}
\hline Cow & $\begin{array}{c}\text { Zinc } \\
\text { bacitracin } \\
\text { g/day }\end{array}$ & $\begin{array}{l}\text { Experimental } \\
\text { period and } \\
\text { day }\end{array}$ & $\begin{array}{c}\text { Remaining } \\
\text { on } 1.0 \mathrm{~mm} \\
\text { sieve }\end{array}$ & $\begin{array}{c}\text { Remaining } \\
\text { on } 0.5 \mathrm{~mm} \\
\text { sieve }\end{array}$ & $\begin{array}{c}\text { Remaining } \\
\text { on } 0.1 \mathrm{~mm} \\
\text { sieve }\end{array}$ & Total & $\begin{array}{c}\text { Passing through } \\
0.1 \mathrm{~mm} \\
\text { sieve }\end{array}$ \\
\hline Nopea & - & 0 -period, day 14 & 5.6 & 12.9 & 30.7 & 49.2 & 50.8 \\
\hline$"$ & 20 & 1-period, day 11 & 8.7 & 18.9 & 26.3 & 53.9 & 46.1 \\
\hline$"$ & 28 & 2-period, day 7 & 6.1 & 13.6 & 32.4 & 52.1 & 47.9 \\
\hline$"$ & 40 & 3-period, day 3 & 13.3 & 16.0 & 21.7 & 51.0 & 49.0 \\
\hline Ilmu & - & 0 -period, day 14 & 5.0 & 12.0 & 30.6 & 47.6 & 52.4 \\
\hline$"$ & 25 & 1-period, day 11 & 5.9 & 16.0 & 27.8 & 49.7 & 50.3 \\
\hline$"$ & 35 & 2-period, day 7 & 5.9 & 12.9 & 31.6 & 50.4 & 49.6 \\
\hline 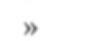 & 50 & 3-period, day 8 & 8.8 & 12.4 & 30.5 & 51.7 & 48.3 \\
\hline
\end{tabular}

The depressing effect of zinc bacitracin on the mincing of hay may actually be somewhat stronger than is suggested by Table 3 . It was seen in the preceding section that large doses of the antibiotic decreased the consumption of feed. This makes it possible for the feed to be more thoroughly ground since it has been shown that smaller amounts of food stay a proportionally longer time in the rumen and the mouth than larger ones (PALOHEIMO and MÄKELÄ 1952, 1959). In spite of this, the antibiotic depressed mastication.

Digestibility. For the invetigations of the digestibility of the feed, faeces samples were taken from both cows in Period 0, from Nopea in Period 2 (Zn-bacitracin $28 \mathrm{~g} /$ day) and from Ilmu in Period 3 (Zn-bacitracin $50 \mathrm{~g} /$ day). Tables 4 and 5 show the results of the analysis, the digestibility percentages and the amounts of digestible nutrients in the different experimental periods.

From the hay and faeces samples determinations were made of dry matter, ash, crude protein and cell wall substances, the last mentioned being determined as the sum of their chemical fractions (SALO 1965). The cell wall substances were also determined as a complex from hay by the method of Paloheimo and Vainio (1965) and from the faeces by the method of Paloheimo and Syrjälä (unpublished, see also Pulliainen, Paloheimo and SyrJÄLÄ 1968, p. 8). In the latter method the exogenous material of the faeces is separated from the endogenous and bacterial material by ultrasonic treatment and filtration through glass sinter. The cell wall complex is obtained from a certain crude fraction (F-fraction) by extraction with $80 \%(\mathrm{v} / \mathrm{v})$ ethanol and by using ash and crude protein corrections. $0.05 \mathrm{~N}$ acid fibre was determined by the method of Palohermo (1945) with a small modification. In the case of the faeces samples it was determined from the F-fraction after ethanol extraction. From the hay samples also crude fibre determinations were made, using the Weende method as modified by Puranen and Tomula (ref. PAlohermo 1969), as well as water soluble sugars (SAlo 1965).

Crude lignin was determined by the method of SALO (1965) and corrected for protein to obtain the value for pure lignin. This substance, referred to simply as lignin, was supposed to be completely indigestible and was selected as the indicator in the digestibility trial. Although digestibility values calculated in this way are not very exact, they show the effect of the antibiotic supplement on the digestibility of the food. 
In compiling the right-hand parts of Tables 4 and 5 it was supposed that the exogenous organic matter of the faeces equals the organic matter of the F-fraction. This being so, the exogenous crude protein of the faeces equals the crude protein of the F-fraction. Further the exogenous $\mathrm{N}$-free organic cell enclosure substances equal the exogenous $\mathrm{N}$-free organic matter minus the cell wall complex. The digestibility values in the left-hand part of the tables show the apparent digestibility of hay, with the exception of the values of the cell wall complex, which are true. The values in the right-hand part show the true digestibility.

Table 4 shows that the cows digested a relatively small proportion of the dry matter of the hay: Nopea $51.9 \%$ and Ilmu $49.0 \%$. This was at least partly due to the fact that the hay was not of very good quality although it was blooming timothy hay (crude fibre $34.8 \%$ of dry matter). Its sugar content was only $5.8 \%$ of the dry matter.

In the cow Nopea $28 \mathrm{~g}$ of zinc bacitracin per day decreased the digestibility of the organic matter by about $10 \%$-units, although it had no effect on the hay consumption (Table 1). The decrease in the digestibility of the cell wall complex and the hemicellulose was also about $10 \%$-units, while that of the cellulose was 7.8.

Table 4. The dry matter and chemical components of hay and faeces as percentages of dry weight and the digestibility percentages in different experimental periods.

\begin{tabular}{|c|c|c|c|c|c|c|c|c|c|c|c|c|c|c|c|c|c|}
\hline & \multirow[b]{2}{*}{ 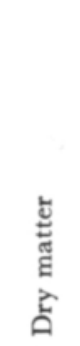 } & \multirow[b]{2}{*}{ 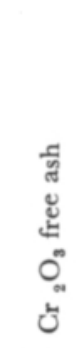 } & \multirow[b]{2}{*}{ 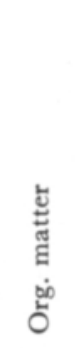 } & \multirow[b]{2}{*}{ 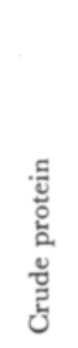 } & \multirow[b]{2}{*}{ 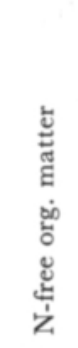 } & \multirow[b]{2}{*}{ 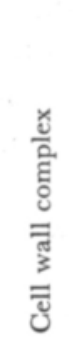 } & \multirow[b]{2}{*}{ 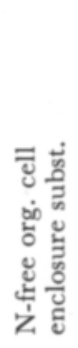 } & \multirow[b]{2}{*}{ 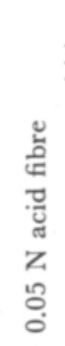 } & \multicolumn{6}{|c|}{$\begin{array}{l}\text { Cell wall subst. (SALO's meth.) } \\
\text { Hemicellulose }\end{array}$} & \multicolumn{3}{|c|}{ Exogenous $^{2}$} \\
\hline & & & & & & & & & 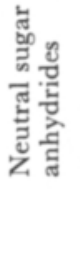 & 窇 & $\frac{\mathscr{o}}{\mathrm{J}}$ & 売 & స్త్ & 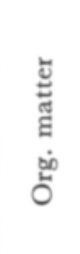 & 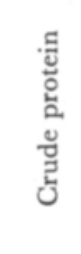 & 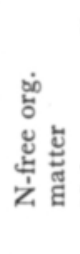 & 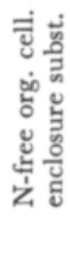 \\
\hline $\begin{array}{l}\text { Hay } \\
\text { Faeces: } \\
\text { Cow Nop }\end{array}$ & 88.3 & 7.3 & 92.7 & 10.9 & 81.8 & 65.6 & 16.2 & 54.4 & 21.3 & 4.2 & 26.8 & 9.6 & 61.9 & 92.7 & 10.9 & 81.8 & 16.2 \\
\hline 0 -period & 17.4 & 11.6 & 88.4 & 11.3 & 77.1 & 54.5 & 22.6 & 47.3 & 18.2 & 4.7 & 20.4 & 19.9 & 63.2 & 58.2 & 1.8 & 56.4 & 1.9 \\
\hline $\begin{array}{l}2-" n \\
\text { Cow Ilm }\end{array}$ & 17.2 & 9.3 & 90.7 & 11.5 & 79.2 & 57.2 & 22.0 & 51.5 & 19.3 & 4.8 & 21.0 & 17.0 & 62.1 & 61.3 & 1.9 & 59.4 & 2.2 \\
\hline 0 -period & 15.5 & 10.3 & 89.7 & 13.8 & 75.9 & 51.9 & 24.0 & 45.3 & 18.2 & 4.3 & 18.4 & 19.0 & 59.9 & 55.8 & 1.9 & 53.9 & 2.0 \\
\hline $\begin{array}{l}3-" \Rightarrow \\
\text { Digestibil } \\
\text { Cow Nop }\end{array}$ & $\begin{array}{r}19.7 \\
\text { llity \% } \\
\text { pea }\end{array}$ & $\begin{array}{l}10.6 \\
\text { : }\end{array}$ & 89.4 & 13.0 & 76.4 & 56.2 & 20.2 & 48.9 & 18.3 & 4.5 & 19.7 & 17.4 & 59.9 & 60.4 & 2.3 & 58.1 & 1.9 \\
\hline 0 -period & 51.9 & 23.3 & 54.2 & 50.5 & 54.6 & 60.1 & 32.7 & 58.1 & 58.7 & 45.2 & 63.4 & 0.0 & 50.9 & 69.8 & 91.7 & 66.9 & 94.4 \\
\hline $\begin{array}{l}2-" n \\
\text { Cow Ilm }\end{array}$ & 43.3 & 27.4 & 44.6 & 40.4 & 45.1 & 50.6 & 22.8 & 46.3 & 48.8 & 35.7 & 55.6 & 0.0 & 43.1 & 62.5 & 89.9 & 58.8 & 92.6 \\
\hline 0 -period & 49.0 & 27.4 & 50.7 & 35.8 & 52.7 & 59.6 & 24.7 & 57.5 & 56.3 & 47.6 & 64.9 & 0.0 & 50.7 & 69.3 & 90.8 & 66.4 & 93.8 \\
\hline 3- " & 45.2 & 20.5 & 47.1 & 34.9 & 48.8 & 53.0 & 31.5 & 50.7 & 53.1 & 40.5 & 59.7 & 0.0 & 47.0 & 64.3 & 88.1 & 61.1 & 93.8 \\
\hline
\end{tabular}


Table 5. Digestible nutrients, expressed as g per $100 \mathrm{~g}$ of dry matter of hay, in different experimental periods.

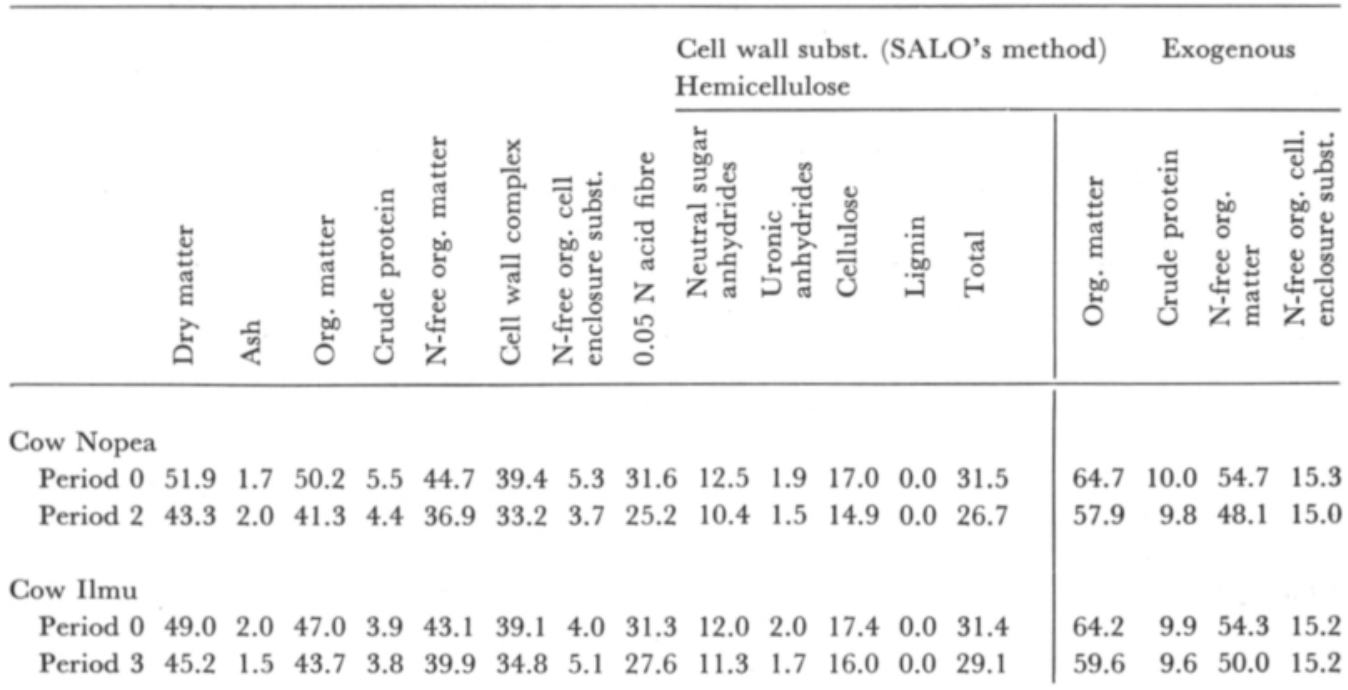

In the cow Ilmu the digestibility values of the hay and its constituents decreased when $50 \mathrm{~g}$ of zinc bacitracin were given per day, but not as much as those of Nopea. It should, however, be noted that Ilmu's hay consumption in Period 3, when the faeces sample was taken for the digestibility investigations, was much lower than in Period 0. It is thus possible that the hay remained in the rumen for a longer time than in the case of Nopea and so was relatively more effectively digested (PALOHEIMo and MÄKELÄ 1952, 1959, van Soest 1965). Thus the depressive effect of the antibiotic on the digestibility of the hay is not so evident with Ilmu as with Nopea.

An examination of Table 4 reveals rather large differences between the values for true digestibility and those for apparent digestibility. As regards crude protein, the former values are as much as $55 \%$-units higher in the case of Ilmu in Period 0. In Period 3 the corresponding figure is 53.2. In the case of Nopea the true digestibility of the crude protein is about $50 \%$-units higher than the apparent digestibility. The digestibility percentages of the $\mathrm{N}$-free organic cell enclosure substances are of interest. Their apparent digestibility values are very low, $22.8-32.7 \%$, being only about half of the values of the cell wall complexes, while the corresponding true digestibility values are much higher varying from $92.6 \%$ to $94.4 \%$ in the different periods. This shows how deceptive the digestibility figures can be, if the exogenous material of the faeces is not separated from the endogenous and bacterial material.

On the whole Ilmu tolerated zinc bacitracin better than Nopea. During the experiment the cows were in good condition, but both decreased in weight by $5.8 \%$.

A c k n o w le d g e m en ts. I wish to record my thanks to Professor emeritus Lauri Paloheimo for all his valuable advice during the work, and to Mr. Aimo Vasara, B. Agr., for technical assistance. My thanks are also due to A/S Apothekernes Laboratorium, Norway, which presented the zinc bacitracin used in the experiments. 


\section{REFERENCES}

A-L. (Apothekernes Laboratorium A/S) 1962. Zinc bacitracin as a feed supplement in animal nutritions. A/S Apothekernes Laboratorium for specialpraeparater, Oslo 62 p.

Chance, C. M., Huffman, C. F. \& Duncan, C. W. 1953. Antibiotics in rumen digestion and synthesis. I. The effect of aureomycin on rumen digestion and the passage of nutrients from the rumen during specific intervals after feeding. J. Dairy Sci. 36: 253-259.

Cunha, T. J. 1955. Antibiotics for swine, beef cattle, sheep, and dairy cattle. First international conference on antibiotics in agriculture, 9-17.

Fulghum, R. S., Baldwin, B. B. \& Williams, P. P. 1968. Antibiotic susceptibility of anaerobic ruminal bacteria. Appl. Microbiol. 16: 301-37.

Hungate, R. E. The rumen and its microbes. Academic Press, Inc., 533 p. New York.

Jukes, T. H. 1955. Antibiotics in nutrition. 128 p. New York.

Kloppenstein, T. J., Purser, D. B. \& Tyznik, W. J. 1964. Influence of aureomycin on rumen metabolism. J. Animal Sci. 23: 490-495.

McDonald, P., Edwards, R. A. \& Greenhalg, J. F. D. 1966. Animal nutrition. 407 p. London.

Mrtchell, G. E. Jr., Little, C. O., Kennedy, L. G. \& KarR, M. R. 1969. Ruminal volatile fatty acids concentrations in steers fed antibiotics. J. Animal Sci. 29: 509-511.

Munch-Petersen, E. \& Armstrong, J. 1958. The influence of orally administered oxytetracycline on the rumen bacteria of sheep. Australian J. Exp. Biol. 36: 77.

Palohermo, L. 1945. Determination of total quantity of cell wall constituents in foods and feeds (Preliminary report). J. Scient. Agric. Soc. Finn. 17: 19-21.

- - 1961. Quantitative measurements of the effect of antibiotics upon the digestion and physical fractions of the faeces. Paper presented at the European Symposium: Antibiotics in animal nutrition. Oslo 8th - 11th June 1961.

Palohermo, L. 1962. Food analysis and the evaluation of foods. Nordisk jordbr.forsk. 44: 78-86.

—— 1966. Some remarks on the digestion trials. World Review of Animal Production 2: 86-91.

—— 1969. Weender Analyse. Handbuch der Tierernährung 1: 164-171.

- - \& MÄKEL Ẍ, A. 1952. The rate of passage of food in the digestive tract of ruminants. Preliminary report. J. Scient. Agric. Soc. Finn. 24: 165-169.

—»— \& MÄKEL Ä, A. 1959. Further studies on the retention time of food in the digestive tract of cows. Acta Agr. Fenn. 94.2: 1-25.

—- \& VAInio, K. A. 1965. Determination of the complex of cell wall substances in plant products. J. Scient. Agric. Soc. Finn. 37: 305-312.

—”- SyrJÄLÄ, Liisa \& VAinio, K. A. 1968. Studies on the faeces. J. Scient. Agric. Soc. Finn. 40: $237-246$.

Prins, R. A. 1969. Effect of some antibiotics and sulphonamides on cellulose breakdown by mixed rumen microorganisms in vitro. Br. vet. J. 125, 5: 18-20.

Pulliainen, E., Palohermo, L. \& SyrJälä, Liisa. 1968. Digestibility of blueberry stems (Vaccinium myrtillus) and cowberries (Vaccinium vitis idea) in the willow grouse (Lngopus lagopus) Ann. Acad. Sci. Fenn. Series A. IV. Biologica 126: 1-14.

Purser, D. B., Klopfenstein, T. J. \& Cline, J. H. 1965. Influence of tylosin and aureomycin upon rumen metabolism and the microbial population. J. Animal Sci. 24: 1039-1044.

Rusoff, L. L., HAQ, M. O., Branton, Cecil, Patric, T. E. \& D'Arensbourgh, G. 1952. Report on feeding aureomycin supplement to mature dairy bulls and lactating dairy cows. J. Animal. Sci. 11: 774 .

SAlo, M-L. 1965. Determination of carbohydrate fractions in animal foods and faeces. Acta Agr. Fenn. 105: $1-102$.

Van Soest, P. J. 1965. Symposium on factors influencing the voluntary intake of herbage by ruminants: voluntary intake in relation to chemical composition and digestibility. J. Animal Sci. 24: $834-843$. 


\section{SELOSTUS \\ RUNSAAN SINKKIBASITRASIINIANNOSTUKSEN VAIKUTUS HEINÄN SYÖNTIMÄÄRÄÄN, HIENONTUMISEEN JA SULAVUUTEEN TÄYSIKASVUISELLA MÄREHTIJÄLLÄ}

\section{LIISA SYRJÄLÄ}

\section{Helsingin yliopiston kotieläintieteen laitos}

Märehtijäin rehut sisältävät paljon kettoaineita, joiden hajoitus tapahtuu pääasiassa pötsin mikrobien avulla. Näiden toiminnan tehokkuudesta riippuu siten koko rehun sulavuus ja ravinnollinen arvo. Tässä tutkimuksessa muutettiin pötsin mikrobiston kokoonpanoa syöttämällä koelehmille sinkkibasitrasiinia eri suurina annoksina.

Kokeessa käytettiin kahta lehmää. Ne saivat ainoana rehunaan silputtua timoteiheinää. Antibioottiannosta suurennettiin kokeen aikana, kunnes koelehmät lopettivat heinän syönnin. Koelehmille syötetyt sinkkibasitrasiinimäärät olivat tällöin $80-100 \mathrm{mg}$ elopainokiloa kohti.

Seulontakokeilla seurattiin rehun hienontumista ruoansulatuskanavassa. Karkeiden fraktioiden osuus suureni, kun sinkkibasitrasiiniannostusta lisättiin. Tämä osoittaa rehun hienontumisen heikentyneen.

Rehun sulavuuden tutkimisessa käytettiin johtoaineena ligniiniä. Kokeen tulokset osoittavat sinkkibasitrasiinin heikentäneen selvästi kettoaineiden sulavuutta. Myös heinän muiden aineosien sulavuus aleni sinkkibasitrasiinia lehmille syötettäessä. 